\title{
Hydric ecosystem services in a non-disturbed rainforest of the Amazon, Amapá, Brazil
}

Understanding the processes of the hydrological cycle of tropical forests reduces the uncertainties about water vapor estimates on a regional scale. Interception refers to water that does not participate directly in ecological processes. Thus, we investigated the interception process using 30 pluviometers, spaced one kilometer apart, within an area of $25 \mathrm{~km}^{2}$ of the Amapá National Forest (FLONA Amapá). The total precipitation above the canopy was $2184.2 \mathrm{~mm}$, and the internal precipitation was $1322.4 \mathrm{~mm}$, representing a fraction of $60.5 \%$. The estimated intercepted fraction was $828.3 \mathrm{~mm}$, corresponding to $37.9 \%$ of the total precipitation above the canopy. As consequence of this water balance, approximately $828.3 \mathrm{~L} . \mathrm{m}-2$ of rainwater was temporarily retained by the forest and returned to the atmosphere as water vapor. We concluded that FLONA Amapá $\left(4120 \mathrm{Km}^{2}\right)$ returns about $1.36 \times 106$ Olympic swimming pools to the atmosphere, annually. The moisture produced in this process, locally cools the air that is transported to other regions of Brazil. This process is a relevant ecosystem service to produce water vapor, confirming the hypothesis that tropical forests are effectively promoting the dynamic balance of the hydrological cycle in the Amazon basin.

Keywords: Climate; FLONA Amapá; Environmental services.

\section{Serviços ecossistêmicos hídricos em floresta não perturbada na Amazônia, Amapá, Brasil}

\begin{abstract}
Compreender os processos do ciclo hidrológico de florestas tropicais reduz as incertezas sobre estimativas de vapor de água em escala regional. A interceptação refere-se à água que não participa diretamente de processos ecológicos. Assim, o processo de interceptação foi investigado com a instalação de 30 pluviômetros, distanciados de um quilômetro, numa área total de $25 \mathrm{~km}^{2}$ da Floresta Nacional do Amapá (FLONA Amapá). A precipitação total observada acima do dossel foi de $2184,2 \mathrm{~mm}$ e a precipitação interna foi de $1322,4 \mathrm{~mm}$, representando uma fração de $60,5 \%$. A fração interceptada estimada foi de $828,3 \mathrm{~mm}$, correspondendo a $37,9 \%$ da precipitação total acima do dossel. Como resultado deste balanço hídrico, cerca de $828,3 \mathrm{~L} / \mathrm{m}^{2}$ ano de água da chuva foi temporariamente retida pela floresta e retornada à atmosfera como vapor d'água. Conclui-se que a FLONA Amapá $\left(4120 \mathrm{Km}^{2}\right)$ retorna cerca de 1,36 x 106 piscinas olímpicas à atmosfera anualmente. A umidade produzida neste processo resfria o ar localmente, o qual é transportado para outras regiões do Brasil. Este processo configura-se num relevante serviço ecossistêmico de produção de vapor d'água, confirmando a hipótese de que as florestas tropicais são efetivamente promotoras do equilíbrio dinâmico do ciclo hidrológico na bacia Amazônica.
\end{abstract}

Palavras-chave: Clima; FLONA Amapá; Serviços ambientais.

Topic: Meteorologia e Climatologia

Reviewed anonymously in the process of blind peer.
Received: 05/09/2020

Approved: 09/11/2020
Leidiane Leão de Oliveira (iD)

Universidade Federal do Oeste do Pará, Brasil http://lattes.cnpq.br/5016148560650320 http://orcid.org/0000-0002-5995-9107

leidianeoli@gmail.com

Luis Gustavo de Castro Canani

Instituto do Estado do Pará, Brasil

http://lattes.cnpq.br/6273864055158415

http://orcid.org/0000-0001-5508-7594

Igustavocc@gmail.com

Naurinete de Jesus da Costa Barreto (iD

Instituto Nacional de Pesquisas Espaciais, Brasil

http://lattes.cnpq.br/9415435965900811

http://orcid.org/0000-0001-5167-6228

netebarreto@gmail.com

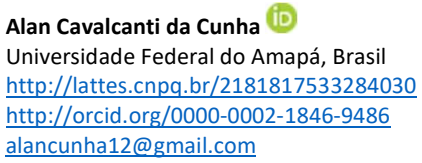

Alan Cavalcanti da Cunha (D)

Universidade Federal do Amapá, Brasil http://lattes.cnpq.br/2181817533284030 http://orcid.org/0000-0002-1846-9486 alancunha12@gmail.com

Referencing this:

OLIVEIRA, L. L.; CANANI, L. G. C.; BARRETO, N. J. C.; CUNHA, A. C.. Hydric ecosystem services in a non-disturbed rainforest of the Amazon, Amapá, Brazil. Nature and Conservation, v.13, n.4, p.45-54, 2020. DOI: http://doi.org/10.6008/CBPC2318-2881.2020.004.0006 


\section{INTRODUCTION}

Interception is the part of rainfall that is retained above the soil surface (TUCCI, 2014). This phenomenon can be due to physical interference from vegetation or any other type of barrier that prevent surface runoff. In the Amazon rainforest, interception provides at least two environmental services related to the hydrological cycle that are relevant to ecosystems: a) rainforest maintenance (FOLEY et al., 2007) and b) water-vapour transport to the central and southern Brazilian regions, and neighbour countries (FEARNSIDE, 2008).

Canopy interception occurs when the rainwater retained on the rainforest leaves and trunks is subsequently lost by evaporation and returned to the atmosphere. In this sense, environmental services are those provided by nature itself which are essential for maintaining the ecological balance (WUNDER et al., 2008) since, depending on the category of the forest, they can significantly interfere with the water balance of hydrographic basins (BESSI et al., 2018). For example, they can reduce river flow fluctuations throughout the year, and delay or decrease flood peaks (TUCCI, 2014).

Another example is the relationship between the hydrological cycle and the carbon sequestration stored in plant biomass. Interception and evapotranspiration are examples of this interaction between the living biomass and the atmosphere, which is extremely relevant for the rainwater recycling process (OLIVEIRA et al., 2008; NOBRE et al., 1991), and the water-vapour transport to central and southern regions of South America (FEARNSIDE, 2008; MARENGO, 2006; CUNHA et al., 2018). As a result, the Amazon rainforest, for example, is responsible for approximately $10 \%$ of global primary production (WARD et al., 2013). In addition, it foster the respiration of organic matter originated in the soil and nearby rivers, which is considered the primary source of $\mathrm{CO} 2$ supersaturation in the Amazon River, since it emits 0.5 Pg C year-1 (RICKEY et al., 2002), an amount roughly equivalent to carbon sequestered by the rainforest (FIELD et al., 1998; MALHI et al., 2008).

Several studies on the interactions between the vegetation and the components of the hydrological cycle are being carried out in the Amazon (UBARANA, 1996; FERREIRA et al., 2005; OLIVEIRA et al., 2008; CUARTAS et al., 2007), which evidenced that the vegetation-atmosphere interactions are not isolated but are rather feedback processes.

Canopy interception tends to reduce the fluctuations in the flow of surface water bodies and groundwater (BESSI et al., 2018) throughout the year, delaying or reducing maximum flows and flood peaks, and also preventing the excessive impact of part of the rainwater on the soil. Furthermore, it interferes with the Amazonian climate pattern, since interception by dense canopies might favour a greater return of water to the atmosphere, especially during dry periods (DOUGHTY et al., 2015; OLIVEIRA et al., 2011; CUARTAS et al., 2007; SALESKA et al., 2007). Therefore, canopy interception plays a key role in controlling the amount of water vapour in the atmosphere.

However, studies quantifying this phenomenon in preserved rainforests of the Eastern Amazon are extremely scarce. Thus, the aim of this study was to assess the effective relative importance of canopy 
interception in an upland rainforest located in a protected area of the Amapá State. The main hypothesis of this study was that both hydrological aspects (i.e. water balance) and variation in the structural patterns of vegetation would be associated with local and large-scale climatic conditions, significantly influencing the amount of water intercepted by the rainforest (> 30\%).

\section{MATERIALS AND METHODS}

This study was carried out between January 2010 and January 2011, in contour plots located within the area of the project of the Brazilian Program in Biodiversity Research (PPBio), which are placed at the south edge of the National Forest (FLONA) of Amapá. The FLONA of Amapá is characterized as a humid tropical upland forest, located in the centre of the state and next to the "Montanhas do Tumucumaque" National Park (PARNA). It was created by Federal Decree-Law No. 97,630, of April 10, 1989, and currently has an estimated area of 412,000 ha (ICMBio, 2020).

In the south of the Araguari River basin, near the south border of the FLONA, the annual rainfall is c.a. $2,300 \mathrm{~mm}$, and the mean temperature is $26{ }^{\circ} \mathrm{C}$ (OLIVEIRA et al., 2010). The seasonal rainfall climatology in Amapá (1978-2007), which preceded the study period, evidenced that the driest period is in spring (September to November) and the rainiest in autumn (March to May).

The years with rainfall above (or below) normal in Amapá are causally related to the intensification or inhibition of the Intertropical Convergence Zone (ITCZ) over the Eastern Amazon. The ITCZ configuration is linked to the activity of La Niña (or El Niño) over the Tropical Pacific Ocean, which occurs concurrently with the negative (or positive) dipole phase over the Intertropical Atlantic Ocean (CUNHA et al., 2010; CUNHA et al., 2018).

Thirty internal rainfall collectors were installed in the specific study area of the FLONA-AP grid (Figure 1). To facilitate the readings, the collectors were placed at the outset of each plot. Each collector consisted of a $16.5 \mathrm{~cm}$ diam. funnel connected by a hose to a 20 L-container, which was installed below the canopy, 1 $\mathrm{m}$ above the forest floor. The internal rainfall was measured monthly, using a simplified water balance, according to Equation 1.

To estimate losses due to canopy interception, the following equation was used:

$\mathrm{I}=\mathrm{P}-\mathrm{PE}$

Where $\mathrm{I}$ is the interception losses, $\mathrm{P}$ is the rainfall above the canopy, and $\mathrm{PE}$ is the net rainfall (all in $\mathrm{mm}$ ). The throughfall, i.e. the rainfall that actually reaches the soil surface was calculated according to the equation below:

$P E=P I+E S C$

Where PE is the net rainfall, $\mathrm{PI}$ is the internal rainfall, and ESC is the stemflow (all in $\mathrm{mm}$ ). Applying equation (2) in (1), we obtain:

$$
\mathrm{I}=\mathrm{P}-(\mathrm{PI}+\mathrm{ESC})
$$

The topographic variables used in this study were altitude and slope. All contour plots and the plot's starting point were georeferenced using a Garmin GPSMAP 60CSx. As the plots follow a contour, the altitude was constant throughout the plot extension (CASTILHO et al., 2006). 


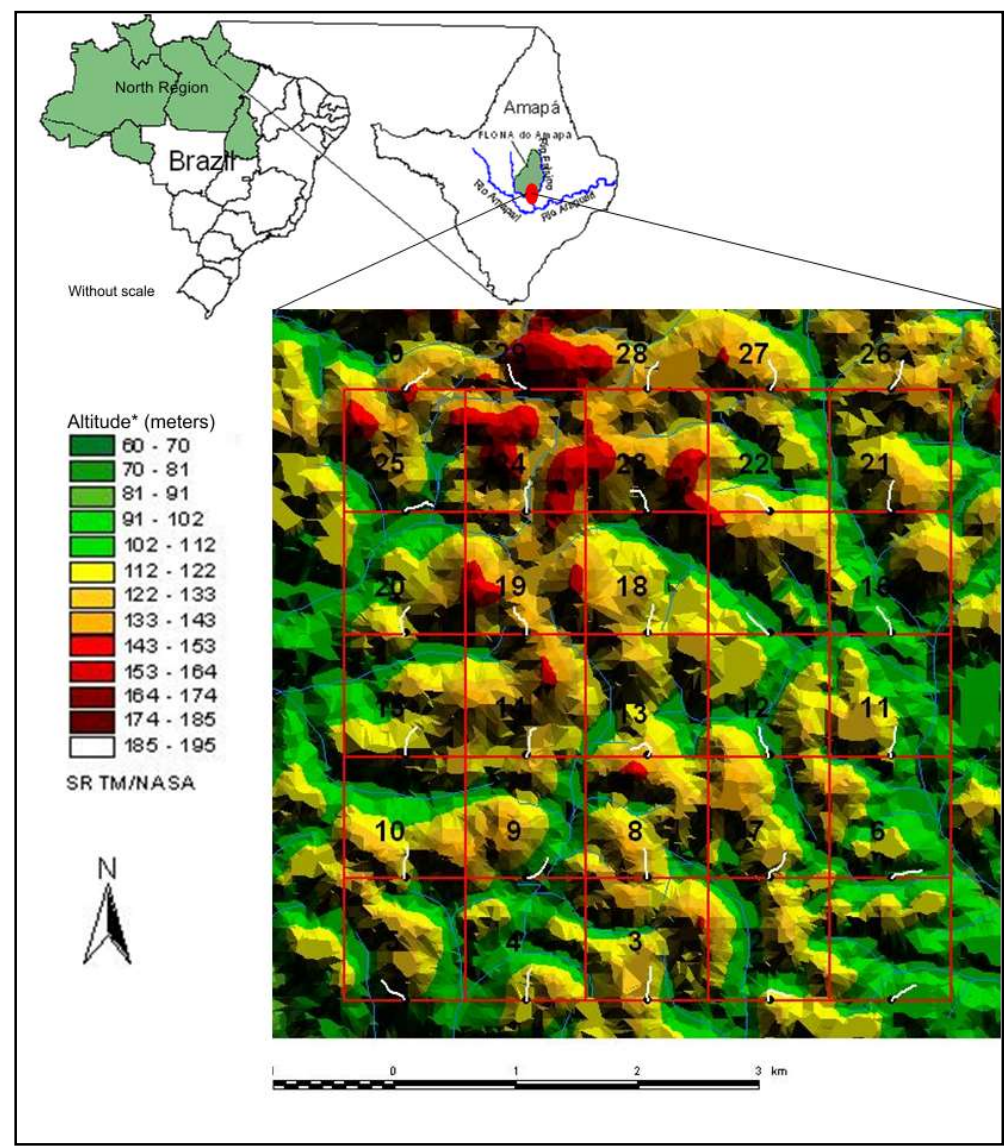

Figure 1: Location map of the Amapá National Forest (FLONA do Amapá) in the State of Amapá, Brazil, and altitude (SRTM) map with the location of the PPBIO grid, and the 30 rain gauges (white lines). Source: PPBIO / IEPA.

The altitude was calculated using terrain images of the Digital Terrain Elevation Model derived from SRTM interferometric radar (Shutter Radar Topographic Mission) data, available from maps provided by the Tropical Biodiversity Research Program (PPBIO-Núcleo Amapá). The terrain slope was measured at six points $(0,50,100,150,200,250 \mathrm{~m})$ along the central line of each plot using a clinometer. At each point, the slope was measured over a $3 \mathrm{~m}$-distance perpendicular to the plot central line ( $1.5 \mathrm{~m}$ on each side of the line). The mean of all measurements was used to represent the plot slope (CASTILHO et al., 2006).

Calculation of the basal area per plot was based on the Diameter at Breast Height (DBH) measured at the plot of the PPBIO project. Statistical analyses and graphical outputs of linear regressions were performed using the software R version 3.3.3 (R CORE TEAM, 2014).

\section{RESULTS AND DISCUSSION}

The total mean rainfall was $2,184.2 \mathrm{~mm} \pm 34.3 \mathrm{~mm}$, the internal rainfall was $1,322.4 \mathrm{~mm} \pm 134.6 \mathrm{~mm}$, and the canopy interception was $828.3 \mathrm{~mm}$. These amounts correspond, respectively, to $60.5 \% \pm 6.6 \%$ and $37.9 \% \pm 7.2 \%$ of the total rainfall above the canopy. The collection from November 2010 to January 2011 showed the highest accumulated rainfall $(625.3 \mathrm{~mm} \pm 0.0 \mathrm{~mm})$, because the spacing between collections was three months (Table 1).

As expected, the accumulated monthly rainfall was the highest ( $565.2 \mathrm{~mm} \pm 35.8 \mathrm{~mm}$ ) between April and May 2010 (Table 1), of which $28.4 \% \pm 12.1 \%$ corresponded to canopy interception (Figure 2A). The lowest monthly rainfall $(70.2 \mathrm{~mm})$ and the highest interception for the study period $(57.9 \% \pm 24.4 \%$ of this 
value; Figure 2F) occurred between October and November 2010 (Table 1). It is important to highlight that the expected maximum intensity of water loss by canopy interception was observed during the dry period.

Table 1: Total precipitation above the canopy (P), Internal precipitation (PI) interception losses (I), for the study period in the 30 plots in FLONA do Amapá.

\begin{tabular}{llllll}
\hline \multirow{2}{*}{ Collection Dates } & \multicolumn{1}{c}{ Total precipitation } & \multicolumn{2}{c}{ Internal precipitation } & \multicolumn{2}{c}{ Interceptation Loss } \\
& \multicolumn{1}{c}{$\mathrm{P}(\mathrm{mm})$} & $\mathrm{PI}(\mathrm{mm})$ & $\mathrm{PI}(\%)$ & \multicolumn{1}{c}{$\mathrm{I}=\mathrm{P}-\mathrm{PI}(\mathrm{mm})$} & $\mathrm{I}=\mathrm{P}-\mathrm{PI}(\%)$ \\
\hline 25-04 to $25-05-10$ & $565.2 \pm 35.8$ & $412.9 \pm 69.8$ & $72.1 \pm 12.1$ & $160.4 \pm 75.3$ & $28.4 \pm 12.1$ \\
25-05 to 23-06-10 & $228.6 \pm 20.7$ & $155.8 \pm 33.4$ & $69.3 \pm 15.2$ & $73.8 \pm 38$ & $22.7 \pm 15.2$ \\
23-06 to 01-08-10 & $314.7 \pm 25.5$ & $231.2 \pm 42.5$ & $73.2 \pm 10.5$ & $83.6 \pm 31.1$ & $26.8 \pm 10.5$ \\
01-08 to 08-09-10 & $265.7 \pm 2.4$ & $123.2 \pm 37.1$ & $46.4 \pm 13.9$ & $142.5 \pm 37.2$ & $53.6 \pm 13.9$ \\
08-09 to 07-10-10 & $114.6 \pm 0.0$ & $89.0 \pm 12.8$ & $77.7 \pm 11.1$ & $25.6 \pm 12.8$ & $22.3 \pm 11.1$ \\
07-10 to 04-11-10 & $70.2 \pm 0.0$ & $29.5 \pm 17.1$ & $42.1 \pm 24.4$ & $40.6 \pm 17.1$ & $57.9 \pm 24.4$ \\
04-11-10 to 21-01-11 & $625.3 \pm 0.0$ & $340.7 \pm 102$ & $54.5 \pm 16.4$ & $284.6 \pm 102.8$ & $45.5 \pm 16.4$ \\
\hline \multicolumn{1}{c}{ Total } & $2,184.2 \pm 34.3$ & $1,322.4 \pm 135$ & $60.5 \pm 6.6$ & $828.3 \pm 162.5$ & $37.9 \pm 7.2$ \\
\hline
\end{tabular}

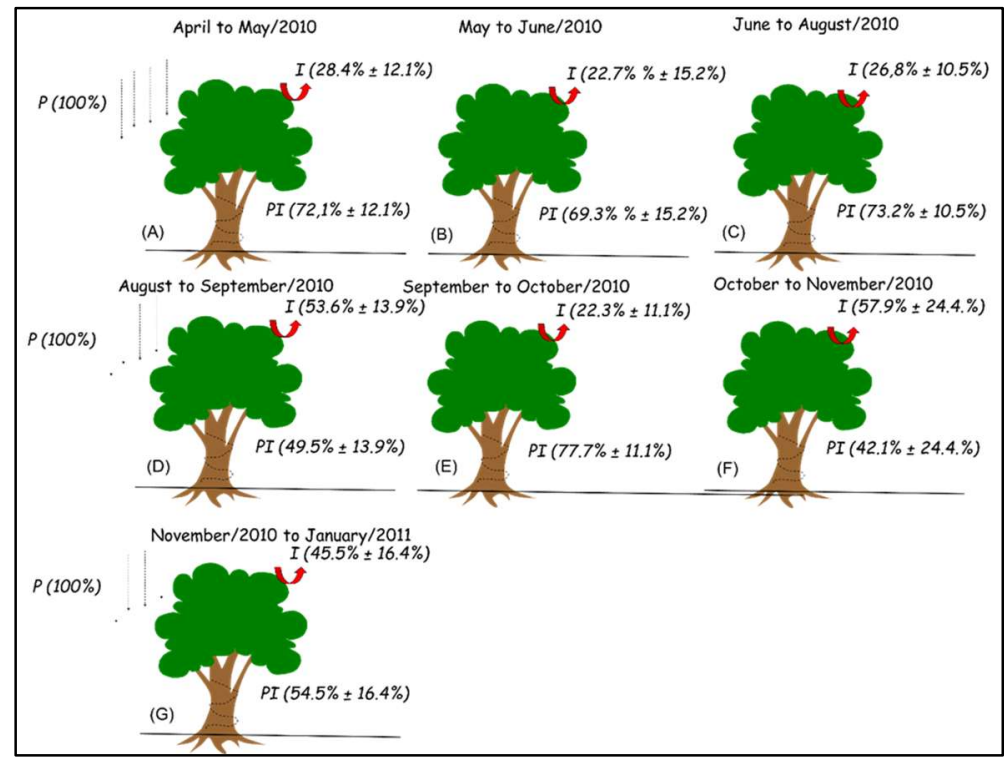

Figure 2: Conceptual water balance model for the present study, considering PT $=100 \%$ for each collection period, for the 30 plots $\left(25 \mathrm{~km}^{2}\right)$ from April 2010 to January 2011.collection period, for the 30 plots $\left(25 \mathrm{~km}^{2}\right)$ from April 2010 to January 2011.

Oliveira et al. (2011) found that in the Eastern Amazon, the canopy interception ranged from 14.9 to $39.6 \%$, with the highest relative value during the dry period, as expected. In the central Amazon, Cuartas et al. (2007) found the highest interception (13.3 to $22.6 \%$ ) during drier years. In a study conducted in a Chilean forest, the net rainfall and interception were, respectively, $67 \%$ and $31 \%$ of the total annual rainfall (DÍAZ et al., 2007).

In our study, the results obtained from the analysis of 30 sampling points indicated that the total rainfall was negatively correlated with the interception $(\%)(R=-0.40 ; p=0.03$; Figure $3 A)$. As expected, the interception decreased as the total precipitation raised. It is estimated that precipitations below $1.6 \mathrm{~mm}$ are totally intercepted by vegetation cover and return to the atmosphere by evaporation (OLIVEIRA et al., 2008; OLIVEIRA JÚNIOR et al., 2005; LIMA et al., 1999; HUBER et al., 1992). Those studies report that, the lower the total precipitation values, the higher the interception values. That is, the higher the total rainfall (TR), the lower the relative interception $(\mathrm{I})$. The interception $(\mathrm{mm})$ was also negatively correlated with the internal rainfall $(m m)(R=-0.70 ; p=0.029 ;$ Figure $3 B)$. 

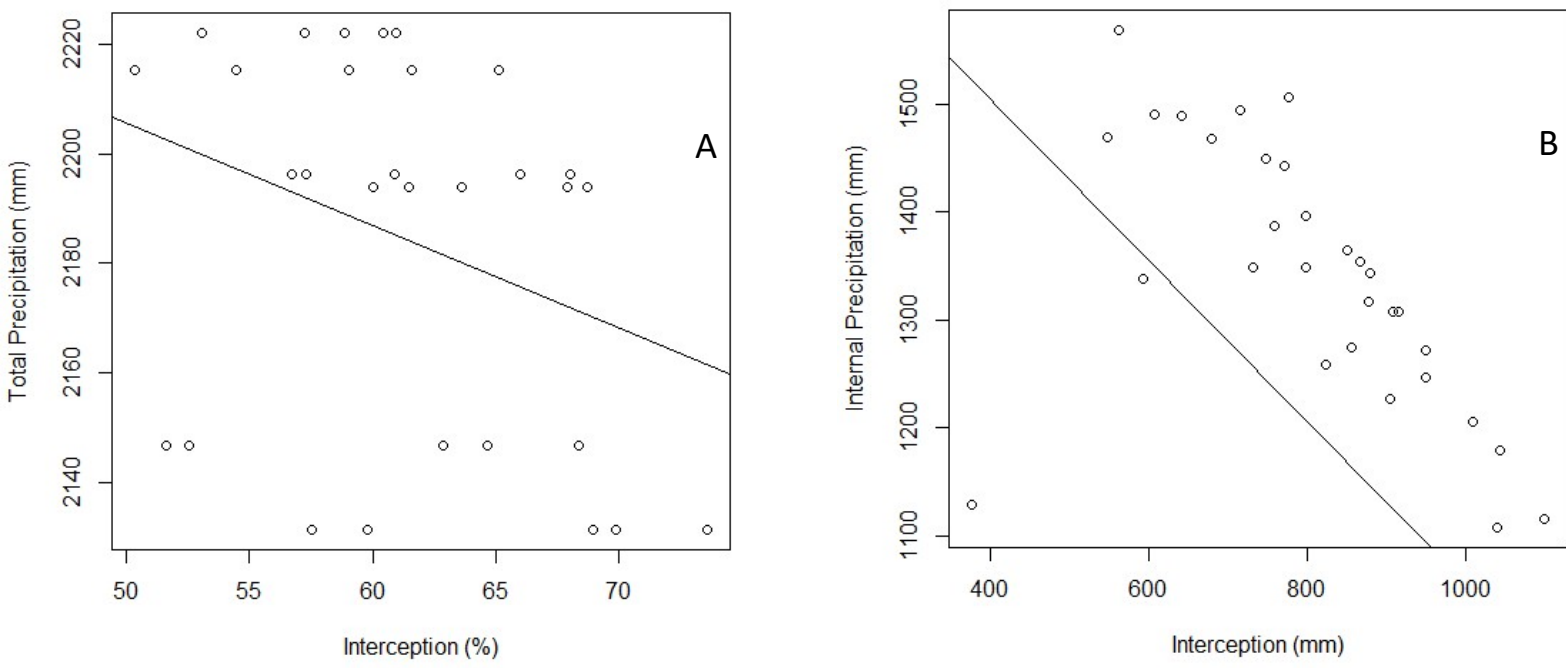

Figure 3: (A) Relationship between PT (mm) and I (\%) for the 30 parcels $\left(25 \mathrm{~km}^{2}\right)$ during April 2010 to January 2011. (B) Relationship between PI (mm) and I (mm) for the 30 plots $\left(25 \mathrm{~km}^{2}\right)$ from April 2010 to January 2011.

On the one hand, as shown in figure 2 , the highest percentage of interception occurred during events or periods of lower rainfall, such as the Amazon summer (July to November). On the other hand, our results also confirmed that the highest levels of interception were associated with the lowest rainfall (Figure 2), as previously reported by Oliveira et al. (2011), Yan et al. (2014) and Doughty et al. (2015).

The interception was not significantly correlated with the slope $(R=0.01 ; p=0.29)$, the basal area ( $=-0.03 ; p=0.33)$ or the altitude $(R=0.04 ; p=0.16)$. However, there was a subtle trend in which the plots with the greatest slopes and the highest altitudes showed the highest levels of rainfall interception, while plots with the largest basal area had the lowest interception. Higher altitude and slope sites receive more solar radiation, a key factor for the interception process. The total interception was higher during the dry period in the eastern Amazon. The interception increased from $14.9 \%$ to $39.6 \%$ from the rainy to the dry period (OLIVEIRA et al., 2011). According to the authors, this was related to the occurrence of isolated precipitation events, which are more likely to the interception process, since they are characterized by scarce and small volumes distributed throughout the vegetation, during the dry season. In addition, the absence of clouds at this time of year increased the number of hours of sunlight, which also contributed to the raise of the interception values. Differences in temperature, light, substrate, humidity, salinity, soil nutrients, besides other factors, have shaped (and still shape) the distribution and adaptation of plants, animals and microbes (RICKLEFS, 2003).

In the present study, a conceptual model of water balance was developed to represent the global process and the relative relevance of the role of interception by the forest canopy for the FLONA-AP grid (Figure 4). Despite its conceptuais simplicity, the water balance results obtained for the grid of FLONA of Amapá (Figure 4 ) indicated that approximately $37.9 \% \pm 7.2 \%$ of the water vapour is annually evaporated back into the atmosphere. Since this relative value comes exclusively from rainwater interception, the throughfall not intercepted by the canopy that reached the forest soil, as internal rainfall, was $60.5 \% \pm 6.6 \%$ (Figure 4). 


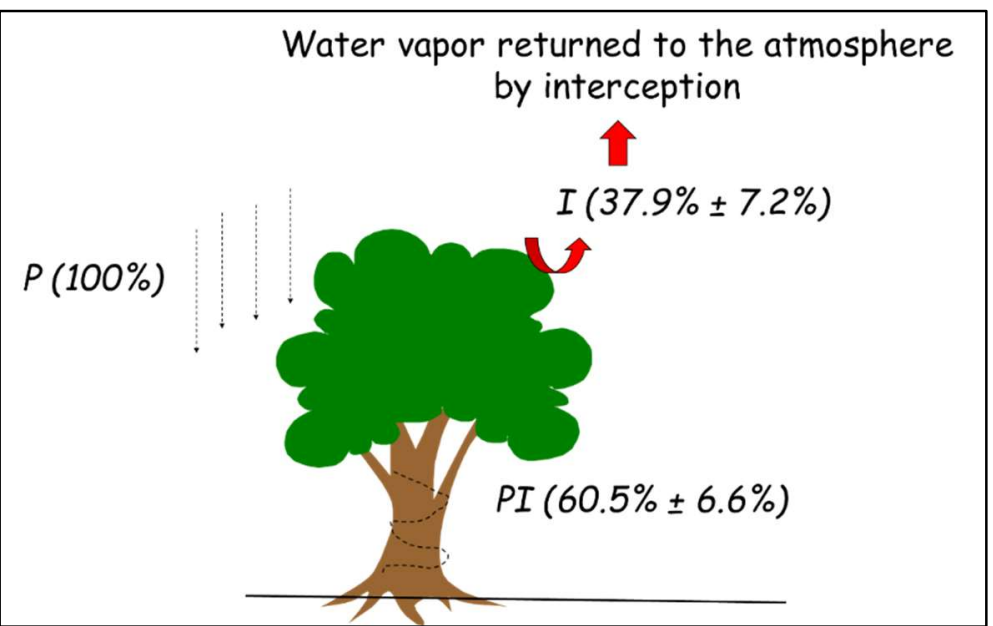

Figure 4: Conceptual model of the water balance for the present study, considering PT $=100 \%, I=37.9 \% \pm$ $7.2 \%$ and $\mathrm{PI}=60.5 \% \pm 6.6 \%$. for the 30 plots $\left(25 \mathrm{~km}^{2}\right)$ from April 2010 to January 2011 .

Giglio et al. (2013) analysed all studies that measured the interception in different forests throughout the Brazilian territory and found that, in the Amazon, the interception ranges between 19.1 and $28.6 \%$, the internal rainfall between 38 and $98.2 \%$ and the stemflow from 0.3 to $41 \%$ of the total rainfall.

In our study, the canopy interception was approximately $38 \% \pm 7.2 \%$, which is slightly above the results found by those authors. The forest structure, especially when heterogeneous, might have been the main factor that contributed to the differences in the results of internal rainfall and canopy interception (FERREIRA et al., 2005). It should be considered that the collectors were installed $1 \mathrm{~km}$ distant from each other in an area of primary forest of $25 \mathrm{~km}^{2}$ within a conservation unit, which allowed us to cover greater landscape heterogeneity.

Our study demonstrates the importance of water balance in a preserved tropical rainforest and its role in hydrological processes involving rainwater cycling. This type of study is extremely scarce, but important for the region to generate basic knowledge about reference hydrological parameters, especially for comparative studies or studies in non-preserved forests (OLIVEIRA et al., 2011). For example, high interception and evapotranspiration contribute to maintaining the water balance and high air humidity in the Amazon region. Consequently, interception contributes to the release of a significant amount of water vapour into the atmosphere, that feeds rainfall-forming systems in the Amazon (MARENGO, 2006; OLIVEIRA et al., 2011; CUNHA et al., 2018). Therefore, together with the air currents, which are dependent on wind intensity, they help transport this water vapour to the south and southeast of Brazil, contributing to the rainfall maintenance in this region. This hydrometeorological dynamic favours the climate balance and regional agriculture, as well as food production in other regions of the country (FEARNSIDE, 2008; MARENGO, 2006).

The referred hydrological flows can be characterized not only as essential and important environmental services, but also as extremely relevant for forest conservation (positive feedback), providing "credits" of water vapour, and contributing to the maintenance of the ecosystem balance in tropical forests (WUNDER et al., 2008; FEARNSIDE, 2008).

Our results showed that approximately $37.9 \% \pm 7.2 \%$ of the rainwater $\left(828.3\right.$ L.m- $^{2}$.year -1$)$ was 
temporarily retained by the rainforest in only $25 \mathrm{~km}^{2}$, and systematically returned to the atmosphere as water vapour. A rough estimate based on this balance indicated that FLONA of Amapá, with an area of 4,120 $\mathrm{km}^{2}$, returns to the atmosphere approximately the volume of water contained in $\approx 1.37 \times 10^{6}$ Olympic swimming pools per year. This water vapour is useful to cool down the regional atmospheric air, that is subsequently transported to other regions of Brazil.

Seventy per cent of the State of Amapá corresponds to areas of environmental protection (PAs), which is the result of the effective implementation of public policies aimed at environmental protection with potential effects at the mesoscale level (DIAS et al., 2016). Thus, the merits of these environmental services to generate "water vapour credits" should be further discussed. However, these processes still need to be comprehensively investigated. Finally, the paradigm of considering carbon sequestration merely as a very relevant process needs to change, in order to recognize its role in hydrological processes that generate water vapour credits and that are intrinsic to complex ecological interactions between forests and water availability in tropical basins. If these processes are better evaluated in economic-environmental analyses, their role would be better recognized as compensation for forest maintenance.

On another hand, the Amazon Basin is the world's largest continental evaporative basin, whose existence as a tropical rain forest depend on abundant rainfall, much of which is recycled moisture. Precipitation recycling from within the basin plays an important role in its water balance and the return of water vapor from the land to the atmosphere is fundamental for the maintenance of the regional water cycle in the Amazon basin (CUNHA et al., 2018). But whereas transpiration is the dominant process, having the extensive vegetation cover as a large single source, evaporation can result from several sources, and their relative importance and location are poorly known (MARTINELLI et al., 1996). Further, climate change is anticipated to impact the overall water cycling in the Amazon basin. There is evidence that climate change has already brought an intensification of the hydrological cycle in Amazonia over the last two decades. Rainfall and minimum runoff have declined, while air temperatures have increased since 1980, particularly during the dry season (DOUGTHY et al., 2015; CUNHA et al., 2018).

It is relevant to evaluate that the climate in the Amazon basin is predicted to change with an intensification of El Niño/La Niña events and its ensuing dry/humid weather. For instance, recent events indicate high tree mortality and hydrological shifts in river levels and lakes. This region will likely suffer from extreme events such as droughts (DOUGHTY et al., 2015), which can cause unpredictable effects on watersheds, directly impacting their drainage systems, human populations, chemistry and the biota of lakes and rivers (CUNHA et al., 2018).

\section{CONCLUSIONS}

Canopy interception is one of the most important ecological processes and should be considered as an ecosystem service whose function is the return of water to the atmosphere. By quantifying interception, this study showed the relative importance of this process and its role in the canopy of tropical forests, especially for water cycling in the atmosphere. 
This study provides basic technical information in areas that have hitherto not been investigated, contributing to a deeper understanding of water balance in environmentally protected rainforests. Thus, the specific study of interception is an unprecedented contribution to the understanding of the interactions between forests and their role as regulators of the local and regional climate. Besides that, we consider that this is the first study to attempt to quantify interception loss in an upland tropical forest of the Amapá State using simple techniques and hydrometeorological parameters under normal climate events of precipitation.

AKNOWLEDGEMENT: Thanks to the Chemistry Laboratory, Sanitation and Environmental Systems Modeling (LQSMSA) and the support from the Brazilian Council of Scientific and Technological Development (CNPq), Grant \# 309684/2018-8.

\section{REFERENCES}

BESSI, D.; TANAKA, M. O.; COSTA, L. A.; CORREA, C. J. P.; TONELLO, K. C.. Forest restoration and hydrological parameters effects on soil water conditions: a structural equation modelling approach. Brazilian Journal of Water Resources, v.23, n.41, 2018.

CASTILHO, C. V.; MAGNUSSON, W. E.; ARAÚJO, R. N. O.; LUIZÃO, R. C. C.; LUIZ̃̃O, F. J.; LIMA, A. P.; HIGUCHI, N.. Variation in aboveground tree live biomass in a central Amazonian forest: effects of soil and topography. Forest Ecology and Management, v.234, p.85-96, 2006.

CUARTAS, L. A.; TOMASELLA, J.; NOBRE, A. D.; HODNETT, M. G.; WATERLOO, M. J.; MÚNERA, J. C.. Interception waterpartitioning dynamics for a pristine rainforest in Central Amazonia: Marked differences between normal and dry years. Agr. Forest. Meteorol., v.145, p.69-83, 2007.

CUNHA, A. C.; SOUZA, E. B.; CUNHA, H. F. A.. Tempo, clima e recursos hídricos: resultados do Projeto REMETAP. Macapá: IEPA, 2010.

CUNHA, A. C.; STERNBERG, L. S. L.. Using stable isotopes 180 and $2 \mathrm{H}$ of lake water and biogeochemical analysis to identify factors affecting water quality in four estuarine Amazonian shallow lakes. Hydrological Processes, v.32, p.1188-1201, 2018. DOI: http://doi.org/10.1002/hyp.11462

DIAS, T. C. A. C.; CUNHA, A. C.; SILVA, J. M. C.. Return on investment of the ecological infrastructure in a new forest frontier in Brazilian Amazonia. Biological Conservation, v.194, p.184-193, 2016. DOI: http://dx.doi.org/10.1016/j.biocon.2015.12.016

DÍAZ, M. F.; BIGELOWC, S.; ARMESTO, J. J.. Alteration of the hydrologic cycle due to forest clearing and its consequences for rainforest succession. Forest Ecology and Management, v.244, n.1-3, p.32-40, 2007.

DOUGHTY, C. E.; METCALFE, D. B.; GIRARDIN, C. A. J. Drought impact on forest carbon dynamics and fluxes in Amazonia. Nature Letter, v.519, p.78-82, 2015. DOI: http://doi:10.1038/nature14213
FEARNSIDE, P. M.. Valoração Econômica e os Serviços Ambientais da Amazônia. In: RIVAS, A.; FREITAS, C. E.; MOURÃO, R. R.. Valoração e instrumentos econômicos aplicados ao meio ambiente: alternativas para proteger a Amazônia. Manaus: Instituto Piatam, 2008, p.55- 67.

FERREIRA, S. J. F.; LUIZÃO, F. J.; DALLAROSA, R. L. G. Precipitação interna e interceptação da chuva em floresta de terra firme submetida à extração seletiva de madeira na Amazônia central. Acta Amazônica. v.35, n.1, p.55-62. 2005

FIELD, C.; BEHRENFELD, M.; RANDERSON, J.; FALKOWSKI, P. Primary production of the biosphere: Integrating terrestrial and oceanic components. Science, v.281, p.237-240, 1998.

FOLEY, J. A.; ASNER, G. P.; COSTA, M. H.; COE, M. T.; DEFRIES, R.; GIBBS, H. K.; HOWARD, E. A.; OLSON, S.; PATZ, J.; RAMANKUTTY, N.; SNYDER, P.. Amazonia revealed: Forest degradation and loss of ecosystem goods and services in the Amazon Basin. Frontiers in Ecology and the Environment, v.5, n.1, p.25-32, 2007.

GIGLIO, J. N; KOBIYAMA, M.. Interceptação da Chuva: Uma Revisão com Ênfase no Monitoramento em Florestas Brasileiras. Revista Brasileira de Recursos Hídricos, v.18 n.2, p.297-317, 2013.

HUBER, A. J.; OYARZÚN, C. E.. Redistribución de las precipitaciones en un bosque siempreverde del sur de Chile. Turrialba, v.42, p.192-9, 1992.

ICMBio. Instituto Chico Mendes de Conservação da Biodiversidade. Unidades de conservação: Amazônia: Floresta Nacional do Amapá - FLONA Amapá. ICMBio, 2020.

LIMA, P. R. A.; LEOPOLDO, P. R.. Interceptação de chuva por mata ciliar na região central do Estado de São Paulo. Energia na Agricultura, v.14, n.3, p.25-33, 1999.

MALHI, Y; ROBERTS, J. R.; BETTS, R.A.; KILLEEN, T. J.; LI, W.; NOBRE, C. A.. Climate change, deforestation, and the fate of the Amazon. Science, v.319, p.169-172, 2008.

MARENGO, J. A.. On the hydrological cycle of the Amazon Basin: A historical review and current state-of-the-art. Revista Brasileira de Meteorologia, v.21, n.3, p.1-19, 2006. 
MARTINELLI, L. A.; VICTORIA, R. L. L.; STERNBERG, S. L.: RIBEIROA, A.; MOREIRA, M. Z.. Using stable isotopes to determine sources of evaporated water to the atmosphere in the Amazon basin. Journal of Hydrology, v.183, p.191204, 1996.

NOBRE, C. A.; SELLERS, P.; SHUKLA, J.. Amazonian deforestation and regional climate change. Journal of Climate, v.4, p. 957-988, 1991.

OLIVEIRA, L. L.; COSTA, R. F.; SOUSA, F. A. S.; COSTA, A. C. L.; BRAGA, A. P.. Precipitação efetiva e interceptação em Caxiuanã, na Amazônia Oriental. Acta Amazonica, v.38, n.4, 2008. DOI: https://doi.org/10.1590/S0044$\underline{59672008000400016}$

OLIVEIRA, L. L.; COSTA, R. F.; COSTA, A. C. L.; SOUSA, F. A. S.; BRAGA, A. P.. Modelagem da interceptação na Floresta Nacional de Caxiuanã, no Leste da Amazônia. Revista Brasileira de meteorologia, v.23, n.3, p.318-326, 2008. DOI: https://doi.org/10.1590/S0102-77862008000300006

OLIVEIRA, L. L.; CUNHA, A. C.; JESUS, E. S.; BARRETO, N. J. C.. Características Hidroclimáticas da bacia do rio Araguari. In: CUNHA, A. C.; SOUZA, E. B.; CUNHA, H. F. A.. Tempo, Clima e Recursos Hídricos: resultados do Projeto REMETAP no Estado do Amapá. Macapá: IEPA, 2010. p.83-96.

OLIVEIRA, L. L.; CUNHA, A. C.; COSTA, A. C. L.; COSTA, R. F.. Sazonalidade e interceptação da chuva na Floresta Nacional em Caxiuanã - Amazônia Oriental. Scientia Plena, v.7, n.10, 2011.

OLIVEIRA JÚNIOR, J. C.; DIAS, H. C. T.. Precipitação efetiva em fragmento secundário da mata Atlântica. Revista Árvore, v.29, n.1, p.9-15, 2005.

R CORE TEAM. R: A Language and Environment for Statistical Computing. R Foundation for Statistical Computing, Vienna,
Austria. Vienna: R Foundation for Statistical Computing, 2014.

RICKEY, J. E.; MELACK, J. M.; AUFDENKAMPE, A. K.; BALLESTER, V. M.; HESS, L. L.. Outgassing from Amazonian rivers and wetlands as a large tropical source of atmospheric CO2. Nature, v.416, p.617-620, 2002.

SALESKA, S. R.; DIDAN, K.; HUETE, A. R.; ROCHA, H. R.. Amazon Forests Green-Up During 2005 Drought. Science, v.318, 2007.

RICKLEFS, R. E.. A economia da Natureza. 5 ed. Guanabara Koogan S.A., 2003

TUCCI, C. E. M.. Hidrologia: Ciência e Aplicação. 4 ed. Porto Alegre: UFRGS, 2014.

UBARANA, V. N.. Observation and modelline of raifall interception at two experimental sites in Amazônia. In: GASH, J. H. C.; NOBRE, C. A.; ROBERTS, J. M.; VICTORIA, R. L.. Amazonian deforestation and climate. Wiley, 1996. p.151162.

WARD, N. D.; KEIL, R. G.; MEDEIROS, P. M.; BRITO, D. C.; CUNHA, A. C.; DITTMAR, T.; YAGER, P. L.; KRUSCHE, A. V.; RICHEY, J. E.. Degradation of terrestrially derived macromolecules in the Amazon River. Nature Geoscience, v.6, p.530-533, 2013.

WUNDER, S.; BORNER, J.; TITO, M. R.; PEREIRA, L.. Pagamentos por Serviços Ambientais: perspectivas para a Amazônia Legal. Brasília: Ministério do Meio Ambiente, 2008.

YAN, W.; DENG, X.; CHEN, X.; TIAN, D.; XIANG, W.; PENG, Y. Long-term variations of rainfall interception in different growth stages of Chinese fir plantations, Hydrological Sciences Journal, n.60, v.12, p.2178-2188, 2015. DOI: http://doi.org/10.1080/02626667.2014.964243

A CBPC - Companhia Brasileira de Produção Científica (CNPJ: 11.221.422/0001-03) detém os direitos materiais desta publicação. Os direitos referem-se à publicação do trabalho em qualquer parte do mundo, incluindo os direitos às renovações, expansões e disseminações da contribuição, bem como outros direitos subsidiários. Todos os trabalhos publicados eletronicamente poderão posteriormente ser publicados em coletâneas impressas sob coordenação da Sustenere Publishing, da Companhia Brasileira de Produção Científica e seus parceiros autorizados. Os (as) autores (as) preservam os direitos autorais, mas não têm permissão para a publicação da contribuição em outro meio, impresso ou digital, em português ou em tradução. 